\title{
GEOLOGIC MAP OF THE SPIRIT LAKE WEST QUADRANGLE, SKAMANIA AND COWLITZ COUNTIES, WASHINGTON
}

\author{
By Russell C. Evarts and Roger P. Ashley
}

\section{INTRODUCTION}

The Spirit Lake West quadrangle is located on the western slope of the Cascade Range in southern Washington about $15 \mathrm{~km}$ north of Mount St. Helens. Bedrock consists of Oligocene volcanic and volcaniclastic rocks and Oligocene to early Miocene shallow-level plutonic rocks forming the core of the Tertiary Cascade volcanic arc. Surficial deposits include drift representing at least two episodes of alpine glaciation as well as eruptive products of Mount St. Helens volcano (Mullineaux and Crandell, 1981; Mullineaux, 1986; Crandell, 1987).

Repeated glacial advances during the Pleistocene sculpted the area into a terrain of considerable relief, i it bedrock exposures are generally restricted to outcrops in high-gradient streams due to the extensive and heavily vegetated surficial cover. Nearly all of the quadrangle is within the area of devastation resulting from the May 18, 1980 , eruption of Mount St. Helens (Lipman and Mullineaux, 1981). A laterally directed pyroclastic blastsurge leveled old-growth forest in this area and buried the countryside under a stratigraphically complex blanket, as thick as $1 \mathrm{~m}$, of ash, lapilli, and blocks (Hoblitt and others, 1981; Moore and Sisson, 1981; Waitt, 1981; Fisher and others, 1987). Subsequent erosion and salvage logging of the denuded slopes, however, has stripped much of this cover as well as older surficial materials. Surficial deposits were entirely removed from slopes above Spirit Lake and along the North Fork Toutle River and South Coldwater Creek by passage of the rockslide-debris avalanche on the morning of May 18 (Voight and others, 1981; Fisher and others, 1987). As a result, exposures of Tertiary bedrock in the Spirit Lake West quadrangle and adjoining areas (Evarts and Ashley, 1993a) are unsurpassed in the western Cascade Range. This area thus provides an exceptional opportunity to examine stratigraphic and structural details of the Tertiary volcanic arc.

\section{ACKNOWLEDGMENTS}

Weyerhaeuser Corporation freely allowed access to their lands in the western part of the quadrangle. We were ably assisted in the field during the early stages of mapping by Rick Bishop, Mike Covey, Jerry Infeld, Mike Lukk, and Carolyn Peterson. Laboratory support during the project was capably provided by Joe Ash, Mary Caress, Mike Covey, Jerry Infeld, Rick Pietropaoli, Scott Petersen, Carolyn Peterson, and especially by Rick
Bishop. We are grateful to LedaBeth Gray, Brent D. Turrin, and James G. Smith for providing K-Ar and ${ }^{40} \mathrm{Ar} /{ }^{39} \mathrm{Ar}$ ages. Much of this work would have been impossible without the continuing logistical support provided by Bobbie Myers and the staff of the David A. Johnston Cascades Volcano Observatory. Discussions over the years with our U.S. Geological Survey colleagues Donald A. Swanson, James G. Smith, Virgil A. Frizzell, Donal R. Mullineaux, and William E. Scott, with Paul E. Hammond of Portland State University, and with William M. Phillips and Michael A. Korosec of the Washington Division of Geology and Earth Resources have been stimulating and informative. Technical reviews of the manuscript by James G. Smith, and William J. Keith and comments on the Quaternary geology by Dwight R. Crandell are especially appreciated.

\section{SUMMARY OF GEOLOGY}

The strata exposed in the Spirit Lake West quadrangle are part of a thick section of middle Tertiary subaerial volcanic rocks that underlies the Mount St. Helens area (Evarts and others, 1987). This section strikes approximately north-south and dips eastward at low to moderate angles, forming the gentle western limb of a major syncline whose axis lies about $15 \mathrm{~km}$ to the east in the French Butte quadrangle (Walsh and others, 1987; Swanson, 1989). The strata are lithologically heterogeneous and stratigraphically complex. Distinctive marker units are absent, and although unconformities have been recognized, their regional significance is unknown; therefore, construction of a formal stratigraphic framework was not attempted, and only lithologic and local informal units are shown on this map. Isotopic age determinations are the most useful data for regional correlations. The age data from this and adjacent areas (table 1; Evarts and others, in press) indicate that the volcanic rocks in the quadrangle erupted between about 36 and $27 \mathrm{Ma}$. Magmatic activity manifested as the epizonal Spirit Lake pluton continued until about $20 \mathrm{Ma}$. A ${ }^{40} \mathrm{Ar} / 39 \mathrm{Ar}$ laser-fusion age for a dike cutting the pluton suggests very minor activity as young as about $9 \mathrm{Ma}$ (table 1).

Many rocks of the quadrangle appear to represent near-source depositional environments characterized by abundant lava flows, pumiceous pyroclastic rocks, coarsegrained epiclastic deposits, fine-grained subvolcanic intrusions, and zones of hydrothermal alteration (Cas and Wright, 1987; Smith, 1993). Stacks of lava flows such as 
those exposed near Coldwater Lake, for example, may represent cross sections through the flanks of mafic shield volcanoes. The concentration of andesitic and basaltic dikes, plugs, and hydrothermally altered areas at the western end of Johnston Ridge possibly includes one or more exhumed subvolcanic vent zones that may have fed overlying lava flows. This area of preferentially east-westtrending dikes appears to be the eastern margin of a large early Oligocene basaltic andesite volcano centered on a plutonic complex at Spud Mountain (Evarts and Ashley, 1990). Phaneritic intrusive rocks such as those that make up the sill complex on Windy Ridge (Twr) may well exemplify deeper zones of volcanic plumbing systems, though whether they actually vented to the surface is unknown. Laterally continuous sections such as that extending from The Dome to Spirit Lake, however, were more likely deposited on dispersal aprons low on the flanks of volcanoes or in intervolcanic lowlands.

Chemical analyses (table 2) demonstrate that lowpotassium subalkaline basalt (less than 52 weight percent $\mathrm{SiO}_{2}$ ) and basaltic andesite (between 52 and 57 weight percent $\mathrm{SiO}_{2}$ ) dominate the section (fig. 1). Dacite and rhyolite (greater than 63 weight percent $\mathrm{SiO}_{2}$ ), although abundant among stratigraphically higher rocks to the east (Evarts and Ashley, 1993a), are rare in the Spirit Lake West quadrangle. More than half of the samples are

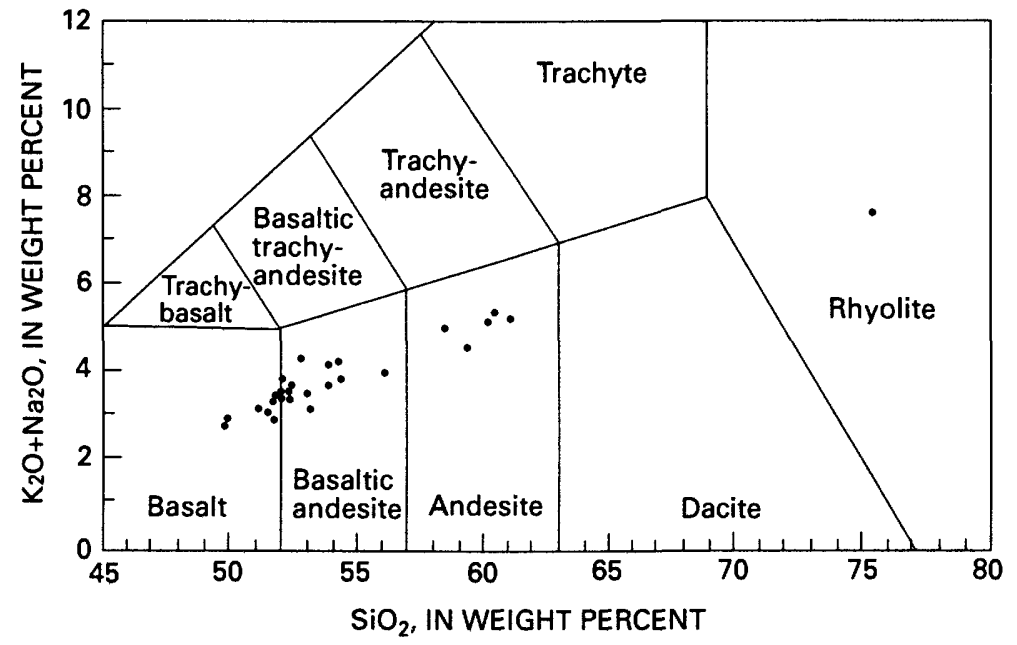

Figure 1. $\mathrm{Na}_{2} \mathrm{O}+\mathrm{K}_{2} \mathrm{O}$ versus $\mathrm{SiO}_{2}$ (recalculated volatile-free) for volcanic and hypabyssal intrusive rocks from Spirit Lake West quadrangle showing classification according to International Union of Geological Sciences (LeBas and Streckeisen, 1991).

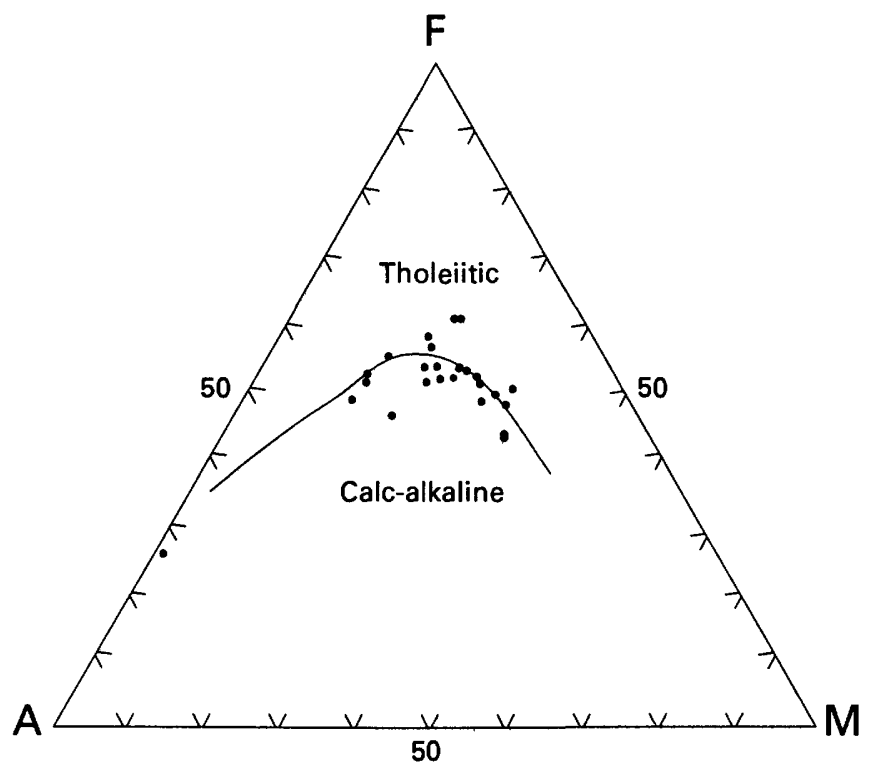

Figure 2. AFM diagram for volcanic and hypabyssal intrusive rocks from Spirit Lake West quadrangle ( $\mathrm{A}, \mathrm{Na}_{2} \mathrm{O}+\mathrm{K}_{2} \mathrm{O} ; \mathrm{F}, \mathrm{FeO}+\mathrm{Fe}_{2} \mathrm{O}_{3}+\mathrm{MnO} ; \mathrm{M}, \mathrm{MgO}$ ). Line separating tholeiitic and calc-alkaline rocks from Irvine and Baragar (1971). 


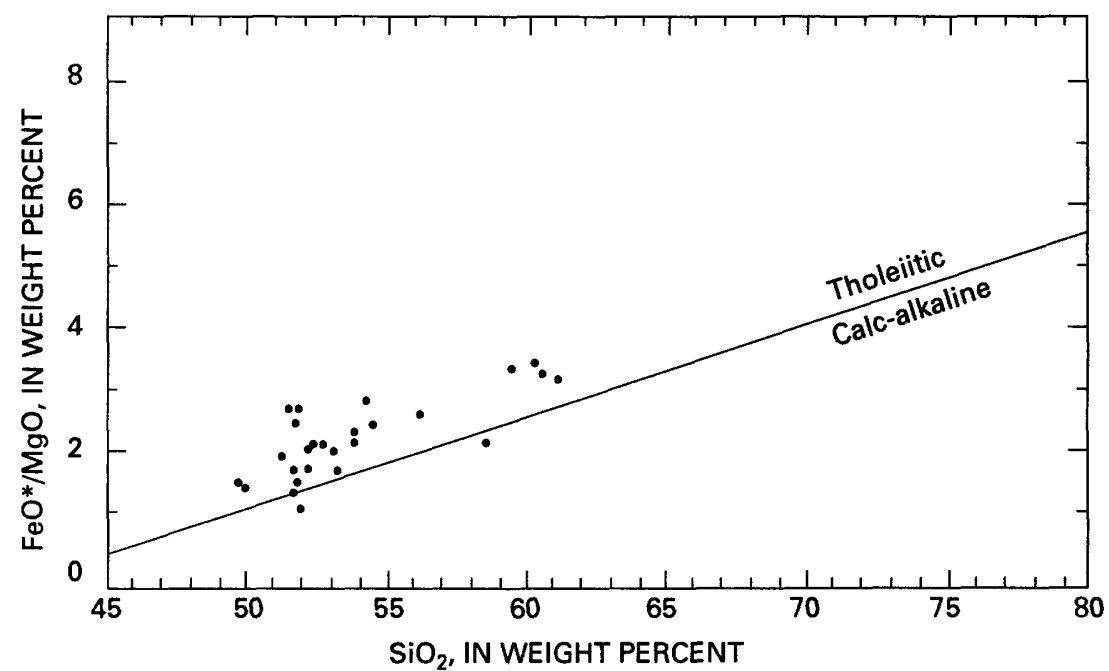

Figure 3. $\mathrm{FeO} / \mathrm{MgO}$ versus $\mathrm{SiO}_{2}$ (recalculated volatile-free) for volcanic hypabyssal intrusive rocks from Spirit Lake West quadrangle showing classification into tholeiitic and calc-alkaline rocks according to Miyashiro (1974). $\mathrm{FeO}^{*}$, total $\mathrm{Fe}$ and $\mathrm{FeO}$.

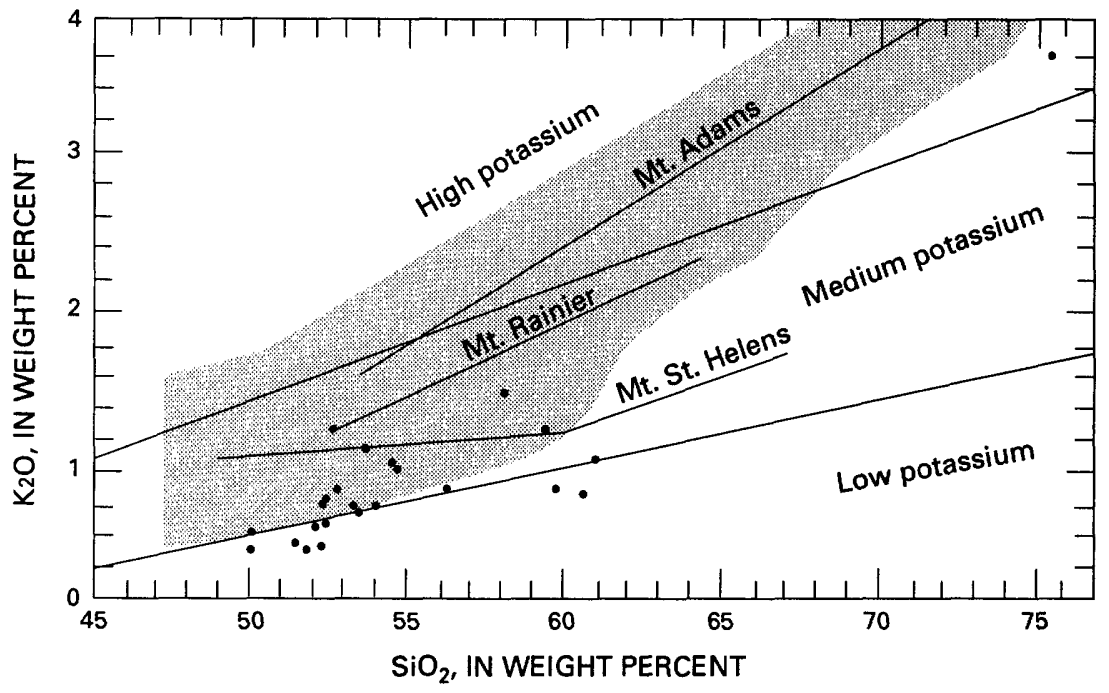

Figure 4. $\mathrm{K}_{2} \mathrm{O}$ versus $\mathrm{SiO}_{2}$ (recalculated volatile-free) for volcanic and hypabyssal intrusive rocks from Spirit Lake West quadrangle [dots]. Low-, medium-, and high-potassium fields from Gill $(1981$, p. 6). Shaded area encompasses compositions of Quaternary volcanic rocks, exclusive of major stratovolcanoes, of southern Washington Cascade Range from Hammond and Korosec (1938). Trendlines shown for Quaternary stratovolcanoes Mount Ranier, Mount St. Helens, and Mount Adams based on data in Condie and Swenson (1973), Hildreth and Fierstein (1985), and Smith and Leeman (1987).

classified as calc-alkaline on the AFM plot (fig. 2) of Irvine and Baragar (1971) whereas most are tholeitic according to the $\mathrm{FeO} * / \mathrm{MgO}$ vs. $\mathrm{SiO}_{2}$ plot (fig. 3) of Miyashiro (1974). The Tertiary rocks tend to be lower in $\mathrm{K}_{2} \mathrm{O}$ than Quaternary volcanic rocks of equivalent $\mathrm{SiO}_{2}$ contents in southern Washington (fig. 4).

A general westward coarsening of textures in the Spirit Lake pluton (informal name) suggests that it has been tilted to the east along with its host rocks, so folding of the Tertiary section must postdate $21 \mathrm{Ma}$, the crystallization age of the pluton (table 1). The age of folding is otherwise poorly constrained, and deformation may have taken place over an extended period (Evarts and others, 1987).

Faults and shear zones are common in the Johnston Ridge-South Coldwater Creek area but scarce elsewhere. All are subvertical, and apparent offsets typically are minor, only rarely exceeding $10 \mathrm{~m}$. Generally, rocks on both sides of faults are the same, and the sense of offset cannot be determined, but local slickensides record both strike-slip and dip-slip movements. Most faults are flanked by white to orange zones of hydrothermally altered rock, 
and some faults are occupied or crossed by Tertiary dikes. Therefore, many faults are probably relatively old and represent local small-scale adjustments to movements of magma within Tertiary volcanic centers. Although fault orientations vary considerably, north to north-northeast trends are most common, possibly reflecting the influence of regional tectonic forces (Evarts and others, 1987).

The most seismically active area in Washington, the St. Helens seismic zone (SHZ) of Weaver and Smith (1983), trends north-northwest through the western part of the quadrangle (see sketch map). The greatest concentration of earthquakes in this zone occurs about 16 $\mathrm{km}$ beneath the Elk Lake area north of Coldwater Creek (Grant and others, 1984). Many mapped faults in this zone approximate the north-south, vertical orientation of fault planes inferred from earthquake focal mechanisms to be responsible for the SHZ (Weaver and others, 1987), but none show evidence of recent movement.

\section{SPIRIT LAKE PLUTON}

The Spirit Lake pluton is one of several large, epizonal, multiphase, granitic intrusions of Miocene age in the Washington Cascade Range (Fiske and others, 1963; Tabor and Crowder, 1969; Hammond, 1979; Evarts and others, 1987). The pluton underlies an area of about 120 $\mathrm{km}^{2}$, most of which lies outside the Spirit Lake West quadrangle to the north and east; only the southwestern quarter of the intrusion is shown on this map. Contacts with country rock are sharp and steep, truncating volcanic stratigraphy at high angles. The granitic rocks exposed in this quadrangle are generally coarser grained and more uniform in texture than those in outcrops to the east. This relationship suggests that the body has been tilted to the east along with its host rocks, so that outcrops in this quadrangle represent the deepest exposed levels in the intrusion.

The pluton consists of three phases that have yielded radiometric ages between 20 and $23 \mathrm{Ma}$. Contacts between phases range from sharp to gradational and are commonly obscured by intense deuteric alteration. Virtually all of the pluton in this quadrangle belongs to the main phase (Tsm), a texturally and compositionally heterogeneous unit of predominantly granodiorite. Field relations and $\mathrm{K}-\mathrm{Ar}$ ages indicate that the quartz-diorite phase (Tsqd), which crops out chiefly in the Vanson Peak and Cowlitz Falls quadrangles to the north and northeast (Evarts and Ashley, 1993b, c), is older, and the granite phase (Tsgr), which was emplaced chiefly near the top of the intrusion in the Spirit Lake East and Cowlitz Falls quadrangles to the east and northeast (Evarts and Ashley, $1993 a, b)$, is slightly younger than the main phase.

Small phaneritic intrusions of dioritic to granodioritic composition are widely scattered throughout the quadrangle. Similar rocks are more abundant to the east in the Spirit Lake East quadrangle (Evarts and Ashley, 1993a). Only the sill complex of Windy Ridge $(24.3 \pm 1.3$ $\mathrm{Ma}$ ) has been dated by isotopic techniques. However, because intrusions within the contact metamorphic aureole of the Spirit Lake pluton are recrystallized, all of these satellitic bodies are inferred to be older than the pluton.

\section{METAMORPHISM}

Tertiary volcanic and intrusive rocks throughout the southern Washington Cascade Range have been overprinted by zeolite-facies burial metamorphism (Fiske and others, 1963; Wise, 1970; Hammond, 1980). Volcanic glass is nearly everywhere replaced by ironbearing smectites that give the rocks their characteristic green colors. Olivine phenocrysts are generally replaced by clots of limonite+smectite, microcrystalline quartz, and (or) carbonate. Orthopyroxene is commonly converted to smectite+titanite, but clinopyroxene remains fresh. Recrystallization of plagioclase is more variable both in extent and mineralogy; partial replacement by albite, calcite, laumontite, stilbite, and various clay minerals is widespread.

A contact metamorphic aureole extends as far as 4 $\mathrm{km}$ beyond the Spirit Lake pluton. Despite thorough mineralogical reconstitution, primary macroscopic textures are typically well preserved and permit protoliths to be determined. The aureole can readily be subdivided in the field into an inner zone of black, flinty, aphanitic amphibole-bearing hornfels and an outer zone of green epidote-bearing hornfels (see sketch map).

\section{HYDROTHERMAL ALTERATION AND MINERALIZATION}

The effects of hydrothermal alteration and mineralization directly related to volcanism or to later plutonic activity are present throughout the Spirit Lake West quadrangle. The most conspicuous type of alteration in the volcanic and sedimentary rocks consists of small areas (less than $1 \mathrm{~km}^{2}$ ) that contain erratically distributed bleached limonitic rocks. Most of these altered areas are closely associated with faults, shear zones, and dike swarms; in detail, the alteration was controlled by fractures and permeable clastic beds, and some unaltered rock remains within the areas of hydrothermal alteration shown on this map. Primary igneous minerals in the altered rocks. Primary minerals in these irregular patches have been totally replaced by carbonate+clay assemblages composed of some combination of kaolinite, montmorillonite, illite, calcite, siderite, dolomite, ankerite, quartz, and limonite. The distribution and mineralogy of these intensely altered areas suggest that they are products of low-temperature, shallow-level, acidic geothermal systems penecontemporaneous with Tertiary volcanism.

In the Spirit Lake pluton and adjacent hornfels, minor pyrite is common as thin fracture coatings and replacements of primary mafic silicate and $\mathrm{Fe}-\mathrm{Ti}$ oxide minerals. Rare veins within the pluton contain quartz and chalcopyrite as well. Preferential weathering of clay-rich supergene alteration zones adjacent to mineralized joints is responsible for a set of prominent northeast-trending topographic lineaments in the area between Spirit Lake and Green River. Sulfides in many of these occurrences are accompanied by fine-grained black tourmaline. 


\section{REFERENCES CITED}

Barnosky, C.W., 1984, Late Pleistocene and early Holocene environmental history of southwestern Washington State, U.S.A.: Canadian Journal of Earth Sciences, v. 21, p. 619-629.

Cas, R.A.F., and Wright, J.V., 1987, Volcanic successions: modern and ancient: London, Allen and Unwin, $528 \mathrm{p}$.

Cashman, K.V., and Taggart, J.E., 1983, Monitoring the 1980-1982 eruptions of Mount St. Helens: compositions and abundances of glass: Science, $v$. 221 , p. $1385-1387$.

Cobbing, E.J., and Pitcher, W.S., 1972, The coastal batholith of central Peru: Journal of the Geological Society of London, v. 128, p. 421-460.

Colman, S.M., and Pierce, K.L., 1981, Weathering rinds on andesitic and basaltic stones as a Quaternary age indicator, western United States: U.S. Geological Survey Professional Paper 1210, 56 p.

Condie, K.C., and Swenson, D.H., 1973, Compositional variation in three Cascade stratovolcanoes: Jefferson, Rainier, and Shasta: Bulletin Volcanologique, v. 37, p. 205-230.

Crandell, D.R., 1987, Deposits of pre-1980 pyroclastic flows and lahars from Mount St. Helens, Washington: U.S. Geological Survey Professional Paper 1444, 91 p.

Crandell, D.R., and Miller, R.D., 1974, Quaternary stratigraphy and extent of glaciation in the Mount Rainier region, Washington: U.S. Geological Survey Professional Paper 847, 59 p.

Criswell, C.W., 1987, Chronology and pyroclastic stratigraphy of the May 18, 1980, eruption of Mount St. Helens, Washington: Journal of Geophysical Research, v. 92, p. 10237-10266.

Dethier, D.P., 1988, The soil chronosequence along the Cowlitz River, Washington: U.S. Geological Survey Bulletin 1590-F, p. F1-F47.

Engels, J.C., Tabor, R.W., Miller, F.K., and Obradovich, J.D., 1976, Summary of K-Ar, Rb-Sr, U-Pb, $\mathrm{Pb}-\alpha$, and fission-track ages of rocks from Washington prior to 1975 (exclusive of Columbia Plateau basalts): U.S. Geological Survey Miscellaneous Field Studies Map MF-710, scale 1:1,000,000.

Evarts, R.C., and Ashley, R.P., 1990, Preliminary geologic map of the Goat Mountain quadrangle, Cowlitz County, Washington: U.S. Geological Survey Open-File Report 90-632, scale 1:24,000.

Evarts, R.C., and Ashley, R.P., 1993a, Geologic map of the Spirit Lake East quadrangle, Skamania County, Washington: U.S. Geological Survey Geologic Quadrangle Map GQ-1679, scale 1:24,000.

- 1993b, Geologic map of the Cowlitz Falls quadrangle, Lewis and Skamania Counties, Washington: U.S. Geological Survey Geologic Quadrangle Map GQ-1682, scale 1:24,000.

- -1993c, Geologic map of the Vanson Peak quadrangle, Lewis, Cowlitz, and Skamania Counties, Washington: U.S. Geological Survey Geologic Quadrangle Map GQ-1680, scale 1:24,000.
Evarts, R.C., Ashley, R.P., and Smith, J.G., 1987, Geology of the Mount St. Helens area: record of discontinuous volcanic and plutonic activity in the Cascade arc of southern Washington: Journal of Geophysical Research, v. 92, p. 10,155-10,169.

Evarts, R.C., Gray, L.B., Turrin, B.D., Smith, J.G., and Tosdal, R.M., in press, Isotopic and fission-track ages of volcanic and plutonic rocks in the Spirit Lake 15minute quadrangle and adjacent areas, southwestern Washington: Isochron West.

Fisher, R.V., Glicken, H.X., and Hoblitt, R.P., 1987, May 18, 1980, Mount St. Helens deposits in South Coldwater Creek, Washington: Journal of Geophysical Research, v. 92, p. 10,267-10,283.

Fiske, R.S., Hopson, C.A., and Waters, A.C., 1963, Geology of Mount Rainier National Park, Washington: U.S. Geological Survey Professional Paper 444, $93 \mathrm{p}$.

Gill, J.B., 1981, Orogenic andesites and plate tectonics: New York, Springer-Verlag, 390 p.

Glicken, H.X., 1986, Rockslide-debris avalanche of May 18, 1980, Mount St. Helens volcano, Washington: Santa Barbara, University of California, Ph.D. dissertation, $303 \mathrm{p}$.

Glicken, Harry, Meyer, William, and Sabol, Martha, 1989, Geology and ground-water hydrology of Spirit Lake blockage, Mount St. Helens, Washington, with implications for lake retention: U.S. Geological Survey Bulletin 1789, $33 \mathrm{p}$.

Grant, W.C., Weaver, C.S., and Zollweg, J.E., 1984, The 14 February Elk Lake, Washington, earthquake sequence: Bulletin of the Seismological Society of America, v. 74, p. 1289-1309.

Hammond, P.E., 1979, A tectonic model for evolution of the Cascade Range, in Armentrout, J.M., Cole, M.R., and TerBest, Harry, Jr., eds., Pacific Coast Paleogeography Symposium 3: Cenozoic paleogeography of the western United States: Pacific Section of the Society of Economic Paleontologists and Mineralogists, Los Angeles, Calif., p. 219-237.

- 1980, Reconnaissance geologic map and cross sections of southern Washington Cascade Range, latitude $45^{\circ} 30^{\prime}-47^{\circ} 45^{\prime} \mathrm{N}$, longitude $120^{\circ} 45^{\prime}$ $122^{\circ} 22.5^{\prime} \mathrm{W}$ : Portland, Oreg., Portland State University, Department of Earth Sciences, scale $1: 125,000$.

Hammond, P.E., and Korosec, M.A., 1983, Geochemical analyses, age dates, and flow-volume estimates for Quaternary volcanic rocks, southern Cascade Mountains, Washington: Washington Division of Geology and Earth Resources Open-File Report 83$13,36 \mathrm{p}$.

Hildreth, W., and Fierstein, J., 1985, Mount Adams: eruptive history of an andesite-dacite stratovolcano at the focus of a fundamentally basaltic volcanic field, in Guffanti, M., and Muffler, L.J.P., eds., Proceedings of the Workshop on geothermal resources of the Cascade Range, May 22-23, 1985, Menlo Park, Calif.: U.S. Geological Survey Open-File Report 85521, p. $44-50$. 
Hoblitt, R.P., Miller, C.D., and Vallance, J.W., 1981, Origin and stratigraphy of the deposit produced by the May 18 directed blast, in Lipman, P.W., and Mullineaux, D.R., eds., The 1980 eruptions of Mount St. Helens, Washington: U.S. Geological Survey Professional Paper 1250, p. 401-419.

Irvine, T.N., and Baragar, W.R.A., 1971, A guide to the chemical classification of the common igneous rocks: Canadian Journal of Earth Sciences, v. 8, p. 523548.

Jackson, L.L., Brown, F.W., and Neil, S.T., 1987, Major and minor elements requiring individual determination, classical whole rock analysis, and rapid rock analysis, in Baedecker, P.A., ed., Methods for geochemical analysis: U.S. Geological Survey Bulletin 1770, p. G1-G23.

Janda, R.J., Scott, K.M, Nolan, K.M., and Martinson, H.A., 1981, Lahar movement, effects, and deposits, in Lipman, P.W., and Mullineaux, D.R., eds., The 1980 eruptions of Mount St. Helens, Washington: U.S. Geological Survey Professional Paper 1250, p. 461-478.

Kuntz, M.A., Rowley, P.D., MacLeod, N.S., Reynolds, R.L., McBroome, L.A., Kaplan, A.M., and Lidke, D.J., 1981, Petrography and particle-size distribution of pyroclastic-flow, ash-cloud, and surge deposits, in Lipman, P.W., and Mullineaux, D.R., eds., The 1980 eruptions of Mount St. Helens, Washington: U.S. Geological Survey Professional Paper 1250, p. 525539.

Kuntz, M.A., Rowley, P.D., MacLeod, N.S., 1990, Geologic maps of pyroclastic-flow and related deposits of the 1980 eruptions of Mount St. Helens, Washington: U.S. Geological Survey Miscellaneous Investigations Map I-1950, scale: 1:12,000.

Le Bas, M.J., and Streckeisen, A.L., 1991, The IUGS systematics of igneous rocks: Journal of Geological Society of London, v. 148, p. 825-833.

Lipman, P.W., and Mullineaux, D.R., eds., 1981, The 1980 eruptions of Mount St. Helens, Washington: U.S. Geological Survey Professional Paper 1250, $844 \mathrm{p}$.

Lipman, P. W., Norton, D.R., Taggart, J.E., Jr., Brandt, E.L., and Engelman, E.E., 1981, Compositional variations in 1980 magmatic deposits, in Lipman, P.W., and Mullineaux, D.R., eds., The 1980 eruptions of Mount St. Helens, Washington: U.S. Geological Survey Professional Paper 1250, p. 631640.

Miyashiro, A., 1974, Volcanic rocks series in island arcs and active continental margins: American Journal of Science, v. 274, p. 321-355.

Moore, J.G., and Sisson, T.W., 1981, Deposits and effects of the May 18 pyroclastic surge, in Lipman, P.W., and Mullineaux, D.R., eds., The 1980 eruptions of Mount St. Helens, Washington: U.S. Geological Survey Professional Paper 1250, p. 421438.

Mullineaux, D.R., 1986, Summary of pre-1980 tephra-fall deposits erupted from Mount St. Helens, Washington state, USA: Bulletin of Volcanology, v. 48, p. 17-26.

Mullineaux, D.R., and Crandell, D.R., 1981, The eruptive history of Mount St. Helens, in Lipman, P.W., and
Mullineaux, D.R., eds., The 1980 eruptions of Mount St. Helens, Washington: U.S. Geological Survey Professional Paper 1250, p. 3-15.

Rowley, P.D., Kuntz, M.A., and MacLeod, N.S., 1981, Pyroclastic-flow deposits, in Lipman, P. and Mullineaux, D.R., eds., The 1980 eruptions of Mount St. Helens, Washington: U.S. Geological Survey Professional Paper 1250, p. 489-512.

Shapiro, Leonard, 1975, Rapid analysis of silicate, carbonate, and phosphate rocks-revised edition: U.S. Geological Survey Bulletin 1401, 76 p.

Smith, D.R., and Leeman, W.P., 1987, Petrogenesis of Mount St. Helens dacitic magmas: Journal of Geophysical Research, v. 92, p. 10,313-10,334.

Smith, J.G., in press, Geologic map of upper Eocene to Holocene volcanic and related rocks in the Cascade Range, Washington: U.S. Geological Survey Miscellaneous Investigations Series Map I-2005, scale $1: 500,000$.

Steiger, R.H., and Jäger, E., 1977, Subcommission on geochronology: convention on the use of decay constants in geo- and cosmochronology: Earth and Planetary Science Letters, v., 36, p. 359-362.

Swanson, D.A., 1989, Geologic maps of the French Butte and Greenhorn Buttes quadrangles, Washington: U.S. Geological Survey Open-File Report 89-309, scale $1: 24,000$.

Tabor, R.W., and Crowder, D.F., 1969, On batholiths and volcanoes-Intrusion and eruption of Late Cenozoic magmas in the Glacier Peak area, north Cascades, Washington: U.S. Geological Survey Professional Paper 604, $67 \mathrm{p}$.

Taggart, J.E., Jr., Lindsay, J.R., Scott, B.A., Vivit, D.V., Bartel, A.J., and Stewart, K.C., 1987, Analysis of geological materials by wavelength-dispersive X-ray fluorescence spectrometry, in Baedecker, P.A., ed., Methods for geochemical analysis: U.S. Geological Survey Bulletin 1770, p. E1-E19.

Voight, Barry, Glicken, Harry, Janda, R.J., and Douglass, P.M., 1981, Catastrophic rockslide-avalanche of May 18, in Lipman, P.W., and Mullineaux, D.R., eds., The 1980 eruptions of Mount St. Helens, Washington: U.S. Geological Survey Professional Paper 1250, p. 347-377.

Waitt, R.B., Jr., 1981, Devastating pyroclastic density flow and attendant air fall of May 18-Stratigraphy and sedimentology of deposits, in Lipman, P.W., and Mullineaux, D.R., eds., The 1980 eruptions of Mount St. Helens, Washington: U.S. Geological Survey Professional Paper 1250, p. 439-458.

Waitt, R.B., Jr., Pierson, T.C., MacLeod, N.S., Janda, R.J., Voight, Bary, and Holcomb, R.T., 1983, Enuption-triggered avalanche, flood, and lahar at Mount St. Helens-Effects of winter snowpack: Science, v. 221, p. 1394-1397.

Walsh, T.J., Korosec, M.A., Phillips, W.M., Logan, R.L., and Schasse, H.W., 1987 Geologic map of Washington-southwest quadrant: Washington Division of Geology and Earth Resources Map GM-34, scale 1:250,000.

Weaver, C.S., and Smith, S.W., 1983, Regional tectonic and earthquake hazard implications of a crustal fault zone in southwestern Washington: Journal of Geophysical Research, v. 88, p. 10,371-10,383. 
Weaver, C.S., Grant, W.C., and Shemata, J.E., 1987, Local crustal extension at Mount St. Helens, Washington: Journal of Geophysical Research, v. 92, p. 10,170-10,178.
Wise, W.S., 1970, Cenozoic volcanism in the Cascade Mountains of southern Washington: Washington Division of Mines and Geology Bulletin 60, 45 p. 
Table 1. Summary of fission-track (FT) and isotopic age determinations, Spirit Lake West quadrangle [Source from Evarts and others (in press) except where noted]

\begin{tabular}{|c|c|c|c|c|c|c|c|c|c|}
\hline \multirow{2}{*}{$\begin{array}{l}\text { Map } \\
\text { No. }\end{array}$} & \multirow{2}{*}{$\begin{array}{l}\text { Field sample } \\
\text { no. }\end{array}$} & \multicolumn{2}{|c|}{ Location } & \multirow{2}{*}{$\begin{array}{l}\text { Map } \\
\text { unit }\end{array}$} & \multirow{2}{*}{ Rock type } & \multirow{2}{*}{$\begin{array}{l}\text { Material } \\
\text { dated }\end{array}$} & \multirow{2}{*}{ Method } & \multirow{2}{*}{$\begin{array}{c}\text { Age (Ma) } \\
( \pm 1 \sigma \text { error })\end{array}$} & \multirow{2}{*}{ Comments } \\
\hline & & Latitude & Longitude & & & & & & \\
\hline \multirow[t]{3}{*}{1} & S81-A5-R48A & $46^{\circ} 16^{\prime} 11^{\prime \prime}$ & $122^{\circ} 13^{\prime} 44^{\prime \prime}$ & $\mathrm{Tb}_{1}$ & $\begin{array}{l}\text { Basaltic } \\
\text { andesite }\end{array}$ & Plagioclase & K-Ar & $27.7 \pm 3.7$ & $\begin{array}{l}\text { Low radiogenic Ar; } \\
\text { minimum age }\end{array}$ \\
\hline & & & & do & -- do-- & Plagioclase & ${ }^{40} \mathrm{Ar} /{ }^{39} \mathrm{Ar}$ & $36.1 \pm 1.0$ & $\begin{array}{l}\text { Laser-fusion } \\
\text { procedure }\end{array}$ \\
\hline & & & & do & - -do- & Plagioclase & ${ }^{40} \mathrm{Ar} /{ }^{39} \mathrm{Ar}$ & $35.2 \pm 0.5$ & Laser-fusion age \\
\hline 2 & S80-B5-E43 & $46^{\circ} 15^{\prime} 05^{\prime \prime}$ & $122^{\circ} 08^{\prime} 33^{\prime \prime}$ & Twr & $\begin{array}{l}\text { Quartz } \\
\text { diorite }\end{array}$ & Hornblende & K-Ar & $24.3 \pm 1.3$ & $\begin{array}{l}\text { Dike related to sill } \\
\text { complex of Windy } \\
\text { Ridge }\end{array}$ \\
\hline \multirow[t]{2}{*}{3} & S79-A4-R128 & $46^{\circ} 20^{\prime} 56^{\prime \prime}$ & $122^{\circ} 12^{\prime} 06^{\prime \prime}$ & Tsm & Granodiorite & Biotite & $\mathrm{K}-\mathrm{Ar}$ & $21.1 \pm 0.6$ & \\
\hline & & & & do & $\longrightarrow$ do-- & Zircon & FT & $21.6 \pm 0.9$ & \\
\hline \multirow[t]{2}{*}{4} & S80-A4-R06 & $46^{\circ} 19^{\prime} 03^{\prime \prime}$ & $122^{\circ} 12^{\prime} 03^{\prime \prime}$ & do & -.--do--- & Biotite & K-Ar & $20.8 \pm 0.6$ & \\
\hline & & & & do & - -do-- & Zircon & FT & $21.9 \pm 0.7$ & \\
\hline 5 & S80-A4-R08 & $46^{\circ} 18^{\prime} 41^{\prime \prime}$ & $122^{\circ} 12^{\prime} 09^{\prime \prime}$ & do & - do-- & Biotite & $\mathrm{K}-\mathrm{Ar}$ & $22.1 \pm 0.7$ & - \\
\hline 6 & SH 119-1 & $46^{\circ} 19.8^{\prime}$ & $122^{\circ} 12.2^{\prime}$ & do & - do- & Hornblende & K-Ar & $21.9 \pm 0.3$ & $\begin{array}{l}\text { Published age (Engels } \\
\text { and others, 1976) } \\
\text { recalraulated using } \\
\text { currently accepted } \\
\text { physical constants } \\
\text { (Steiger and Jäger, } \\
\text { 1977) }\end{array}$ \\
\hline 7 & S79-B4-I05B & $46^{\circ} 19^{\prime} 45^{\prime \prime}$ & $122^{\circ} 08^{\prime} 07^{\prime \prime}$ & Thp & $\begin{array}{l}\text { Homblende } \\
\text { andesite } \\
\text { dike }\end{array}$ & Hornblende & ${ }^{40} \mathrm{Ar} / 39 \mathrm{Ar}$ & $9.7 \pm 0.2$ & $\begin{array}{l}\text { Laser incremental } \\
\text { heating age }\end{array}$ \\
\hline
\end{tabular}


Table 2. Chemical analyses and modes of volcanic and hypabyssal intrusive rocks, Spirit Lake West quadrangle [Oxides in weight percent. For modal analyses, secondary minerals counted as primary mineral replaced; tr: trace; gl+q: interstitial glass+quartz. Rockstype names assigned in accordance with I.U.G.S. systems Le Bas and Streckeisen, 1991; applied to recalculated analyses for volcanic rocks). Methods: RR, single-solution rapid rock analysis as described by Shapiro (1975); analysts, J. Gillison, and H. Smith; XRF, X-ray fluorescence analysis using methods described by Taggart and others, (1987); analysts, A.J. Bartel, D. Siems, K. Stewart and J.E. Taggart; $\mathrm{FeO}, \mathrm{H}_{2} \mathrm{O}$, and $\mathrm{CO}_{2}$ determined using methods described by Jackson and others (1987); analysts, N. Elsheimer, L. Espos and S. Neil. Texture: first term describes overall rock texture; second term describes groundmass.]

\begin{tabular}{|c|c|c|c|c|c|c|c|c|c|}
\hline Map No. & 1 & 2 & 3 & 4 & 5 & 6 & 7 & 8 & 9 \\
\hline $\begin{array}{l}\text { Field sample } \\
\text { Number }\end{array}$ & $9 \mathrm{E} 57$ & $9 \mathrm{E} 37 \mathrm{C}$ & $2 \mathrm{R} 14$ & $6 \mathrm{E} 18 \mathrm{~B}$ & $88 \mathrm{E} 08$ & $6 \mathrm{E} 18 \mathrm{C}$ & 7E31 & 2R37 & 1R38 \\
\hline Latitude & $46^{\circ} 15^{\prime} 47^{\prime \prime}$ & $46^{\circ} 17^{\prime} 34^{\prime \prime}$ & $46^{\circ} 16^{\prime} 39^{\prime \prime}$ & $46^{\circ} 16^{\prime} 11^{\prime \prime}$ & $46^{\circ} 16^{\prime} 57^{\prime \prime}$ & $46^{\circ} 16^{\prime} 12^{\prime \prime}$ & $46^{\circ} 16^{\prime} 29^{\prime \prime}$ & $46^{\circ} 16^{\prime} 50^{\prime \prime}$ & $46^{\circ} 155^{\prime \prime}$ \\
\hline Longitude & $122^{\circ} 08^{\prime} 00^{\prime \prime}$ & $122^{\circ} 12^{\prime} 55^{\prime \prime}$ & $122^{\circ} 12^{\prime} 50^{\prime \prime}$ & $122^{\circ} 11^{\prime} 56^{\prime \prime}$ & $122^{\circ} 14^{\prime} 42^{\prime \prime}$ & $122^{\circ} 12^{\prime} 04^{\prime \prime}$ & $122^{\circ} 12^{\prime} 06^{\prime \prime}$ & $122^{\circ} 14^{\prime} 57^{\prime \prime}$ & $122^{\circ} 10^{\prime} 14^{\prime \prime}$ \\
\hline Map unit & $\mathrm{Tb}_{2}{ }^{1}$ & $\mathrm{~Tb}_{1}$ & $\mathrm{~Tb}_{1}$ & $\mathrm{~Tb}_{1}$ & $T b_{1}$ & $\mathrm{~Tb}_{1}$ & $\mathrm{~Tb}_{1}$ & $\mathrm{~Tb}_{1}$ & Tcp \\
\hline Rock type & Basalt & $\begin{array}{c}\text { Basalt } \\
\text { andesite }\end{array}$ & Basalt & Basalt & Basalt & Basalt & Basalt & Basalt & Basalt \\
\hline Method & $\mathrm{RR}$ & $\mathrm{XRF}$ & $\mathrm{XRF}$ & $\mathrm{XRF}$ & $\mathrm{XRF}$ & $\mathrm{XRF}$ & $\mathrm{XRF}$ & $\mathrm{XRF}$ & $\mathrm{XRF}$ \\
\hline $\mathrm{SiO}_{2}$ & 48.6 & 49.3 & 49.9 & 50.5 & 50.5 & 50.6 & 50.9 & 51.0 & 51.1 \\
\hline $\mathrm{TiO}_{2}$ & 1.0 & 1.82 & 2.17 & 2.11 & 1.24 & 1.63 & 2.22 & 1.28 & 1.23 \\
\hline $\mathrm{Al}_{2} \mathrm{O}_{3}$ & 19.8 & 16.4 & 15.7 & 15.8 & 16.5 & 17.2 & 15.6 & 17.4 & 19.1 \\
\hline $\mathrm{Fe}_{2} \mathrm{O}_{3}$ & 3.1 & 4.55 & 6.76 & 5.26 & 3.19 & 4.58 & 3.63 & 4.26 & 3.58 \\
\hline $\mathrm{FeO}$ & 5.2 & 5.99 & 5.89 & 6.34 & 6.68 & 5.06 & 8.62 & 4.98 & 5.71 \\
\hline $\mathrm{MnO}$ & 0.14 & 0.18 & 0.22 & 0.18 & 0.15 & 0.20 & 0.20 & 0.16 & 0.16 \\
\hline $\mathrm{MgO}$ & 5.3 & 6.97 & 4.45 & 4.33 & 6.98 & 5.16 & 4.37 & 5.89 & 4.52 \\
\hline $\mathrm{CaO}$ & 11.4 & 10.3 & 8.31 & 9.70 & 8.97 & 9.86 & 8.83 & 9.66 & 10.9 \\
\hline $\mathrm{Na}_{2} \mathrm{O}$ & 2.4 & 2.48 & 2.76 & 2.62 & 2.75 & 2.83 & 2.89 & 2.87 & 2.82 \\
\hline $\mathrm{K}_{2} \mathrm{O}$ & 0.27 & 0.36 & 0.20 & 0.20 & 0.51 & 0.35 & 0.38 & 0.54 & 0.29 \\
\hline $\mathrm{P}_{2} \mathrm{O}_{5}$ & 0.16 & 0.22 & 0.32 & 0.39 & 0.19 & 0.25 & 0.34 & 0.17 & 0.14 \\
\hline $\mathrm{H}_{2} \mathrm{O}^{+}$ & 2.3 & 1.61 & 1.86 & 1.87 & 0.91 & 0.99 & 1.40 & 0.98 & 0.79 \\
\hline $\mathrm{H}_{2} \mathrm{O}$ & 0.60 & 0.73 & 1.46 & 0.92 & 1.69 & 1.55 & 0.90 & 1.25 & 0.38 \\
\hline $\mathrm{CO}_{2}$ & 0.02 & 0.07 & 0.05 & $<0.01$ & 0.03 & $<0.01$ & 0.02 & 0.02 & 0.07 \\
\hline Total & $\overline{100.29}$ & $\overline{100.98}$ & $\overline{100.05}$ & $\overline{100.22}$ & $\overline{100.29}$ & $\overline{100.26}$ & $\overline{100.30}$ & $\overline{100.46}$ & $\overline{100.79}$ \\
\hline
\end{tabular}

Analyses recalculated volatile-free and normalized to 100 percent

\begin{tabular}{lrrrrrrrrr}
\hline $\mathrm{SiO}_{2}$ & 49.91 & 50.02 & 51.61 & 51.83 & 51.71 & 51.78 & 51.95 & 51.93 & 51.33 \\
$\mathrm{TiO}_{2}$ & 1.03 & 1.85 & 2.24 & 2.17 & 1.27 & 1.67 & 2.27 & 1.30 & 1.24 \\
$\mathrm{Al}_{2} \mathrm{O}_{3}$ & 20.33 & 16.64 & 16.24 & 16.22 & 16.90 & 17.60 & 15.92 & 17.72 & 19.19 \\
$\mathrm{Fe}_{2} \mathrm{O}_{3}$ & 3.18 & 4.62 & 6.99 & 5.40 & 3.27 & 4.69 & 3.70 & 4.34 & 3.60 \\
$\mathrm{FeO}$ & 5.34 & 6.08 & 6.09 & 6.51 & 6.84 & 5.18 & 8.80 & 5.07 & 5.74 \\
$\mathrm{MnO}$ & 0.14 & 0.18 & 0.23 & 0.18 & 0.15 & 0.20 & 0.20 & 0.16 & 0.16 \\
$\mathrm{MgO}$ & 5.44 & 7.07 & 4.60 & 4.44 & 7.15 & 5.28 & 4.46 & 6.00 & 4.54 \\
$\mathrm{CaO}$ & 11.71 & 10.45 & 8.60 & 9.96 & 9.18 & 10.09 & 9.01 & 9.84 & 10.95 \\
$\mathrm{Na}_{2} \mathrm{O}$ & 2.46 & 2.52 & 2.85 & 2.69 & 2.82 & 2.90 & 2.95 & 2.92 & 2.83 \\
$\mathrm{~K}_{2} \mathrm{O}$ & 0.28 & 0.37 & 0.21 & 0.21 & 0.52 & 0.36 & 0.39 & 0.55 & 0.29 \\
$\mathrm{P}_{2} \mathrm{O}_{5}$ & 0.16 & 0.22 & 0.33 & 0.40 & 0.19 & 0.26 & 0.35 & 0.17 & 0.14 \\
\hline
\end{tabular}

Modes

\begin{tabular}{|c|c|c|c|c|c|c|c|c|c|}
\hline Plagioclase & 18.5 & 0.2 & 0.5 & 5.1 & 18.6 & 9.9 & $-\cdots$ & 5.5 & 34.2 \\
\hline Clinopyroxene & --- & $-\ldots$ & --- & $\operatorname{tr}$ & $\cdots$ & 2.3 & $\ldots$ & $\cdots-\cdots$ & --- \\
\hline Orthopyroxene & $\operatorname{tr}$ & $-\ldots$ & 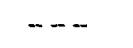 & $\ldots--$ & $\ldots$ & --- & $-\cdots$ & --- & $--\ldots$ \\
\hline Olivine & 0.5 & 6.2 & 0.2 & 0.3 & 4.0 & 4.7 & $-\cdots$ & 4.6 & 0.5 \\
\hline Fe-Ti oxide & $\ldots$ & --- & --- & $\ldots$ & --- & $-\cdots$ & --- & $-\cdots$ & $\ldots$ \\
\hline Homblende & --- & $-\cdots$ & --- & --- & $\cdots$ & --- & $\cdots$ & --- & $\cdots$ \\
\hline Quartz & --- & --- & --- & $\ldots$ & --- & --- & -- & --- & $-\cdots$ \\
\hline Groundmass & 81.0 & 93.6 & 99.3 & 94.6 & 77.4 & 83.1 & 100.0 & 89.9 & 65.3 \\
\hline $\begin{array}{l}\text { No. of points } \\
\text { counted }\end{array}$ & 610 & 655 & 587 & 649 & 744 & 658 & 757 & 814 & 548 \\
\hline Texture & $\begin{array}{l}\text { porphyritic/ } \\
\text { intergranular }\end{array}$ & $\begin{array}{c}\text { seriate/ } \\
\text { intergranular }\end{array}$ & $\begin{array}{l}\text { aphyric/ } \\
\text { intersertal }\end{array}$ & $\begin{array}{l}\text { porphyritic/ } \\
\text { pilotaxitic }\end{array}$ & $\begin{array}{c}\text { seriate/ } \\
\text { intergranular }\end{array}$ & $\begin{array}{c}\text { seriate/ } \\
\text { intergranular }\end{array}$ & $\begin{array}{l}\text { aphyric/ } \\
\text { pilotaxitic }\end{array}$ & $\begin{array}{l}\text { porphyritic/ } \\
\text { intergranular }\end{array}$ & $\begin{array}{c}\text { seriate/ } \\
\text { intergranular }\end{array}$ \\
\hline
\end{tabular}

1 Sample taken from shore of Spirit Lake prior to 1980 eruption of Mount St Helens; locality now beneath surface of Spirit Lake 
Table 2. Chemical analyses and modes of volcanic and hypabyssal intrusive rocks, Spirit Lake West quadrangle-Continued

\begin{tabular}{|c|c|c|c|c|c|c|c|c|c|}
\hline Map No. & 10 & 11 & 12 & 13 & 14 & 15 & 16 & 17 & 18 \\
\hline $\begin{array}{l}\text { Field sample } \\
\text { Number }\end{array}$ & 7E43 & 1R48A & 2E67 & 2R18B & 1E79 & 7E42 & 2E69 & $5 \mathrm{E} 08 \mathrm{C}$ & 9R38 \\
\hline Latitude & $46^{\circ} 16^{\prime} 03^{\prime \prime}$ & $46^{\circ} 16^{\prime} 12^{\prime \prime}$ & $46^{\circ} 18^{\prime} 40^{\prime \prime}$ & $46^{\circ} 17^{\prime} 16^{\prime \prime}$ & $46^{\circ} 17^{\prime} 22^{\prime \prime}$ & $46^{\circ} 15^{\prime} 53^{\prime \prime}$ & $46^{\circ} 18^{\prime} 32^{\prime \prime}$ & $46^{\circ} 19^{\prime} 58^{\prime \prime}$ & $46^{\circ} 17^{\prime} 07^{\prime \prime}$ \\
\hline Longitude & $122^{\circ} 14^{\prime} 22^{\prime \prime}$ & $122^{\circ} 13^{\prime} 44^{\prime \prime}$ & $122^{\circ} 14^{\prime} 42^{\prime \prime}$ & $122^{\circ} 12^{\prime} 47^{\prime \prime}$ & $122^{\circ} 14^{\prime} 44^{\prime \prime}$ & $122^{\circ} 11^{\prime} 11^{\prime \prime}$ & $122^{\circ} 14^{\prime} 13^{\prime \prime}$ & $122^{\circ} 14^{\prime} 53^{\prime \prime}$ & $122^{\circ} 10^{\prime} 14^{\prime \prime}$ \\
\hline Map unit & $\mathrm{Tb}_{1}$ & $\mathrm{~Tb}_{1}$ & $\mathrm{~Tb}_{1}$ & $\mathrm{~Tb}_{1}$ & $\mathrm{~Tb}_{1}$ & $\mathrm{Ta}_{1}$ & Tdi & $\mathrm{Ta}_{1}$ & $T c p$ \\
\hline Rock type & $\begin{array}{l}\text { Basaltic } \\
\text { andesite }\end{array}$ & $\begin{array}{l}\text { Basaltic } \\
\text { andesite }\end{array}$ & $\begin{array}{l}\text { Basaltic } \\
\text { andesite }\end{array}$ & $\begin{array}{l}\text { Basaltic } \\
\text { andesite }\end{array}$ & $\begin{array}{l}\text { Basaltic } \\
\text { andesite }\end{array}$ & $\begin{array}{c}\text { Basaltic } \\
\text { andesite }\end{array}$ & Diorite & $\begin{array}{l}\text { Basaltic } \\
\text { andesite }\end{array}$ & $\begin{array}{l}\text { Basaltic } \\
\text { andesite }\end{array}$ \\
\hline Method & $\mathrm{XRF}$ & $\mathrm{RR}$ & $\mathrm{XRF}$ & $\mathrm{XRF}$ & $\mathrm{XRF}$ & $\mathrm{XRF}$ & $\mathrm{XRF}$ & $\mathrm{XRF}$ & $\mathrm{XRF}$ \\
\hline $\mathrm{SiO}_{2}$ & 51.3 & 51.5 & 51.50 & 51.60 & 52.10 & 52.20 & 52.60 & 53.10 & 53.40 \\
\hline $\mathrm{TiO}_{2}$ & 1.53 & 0.95 & 1.35 & 1.58 & 1.38 & 1.34 & 1.33 & 1.58 & 1.49 \\
\hline $\mathrm{Al}_{2} \mathrm{O}_{3}$ & 17.5 & 15.8 & 18.80 & 16.70 & 18.50 & 16.50 & 17.70 & 16.60 & 17.50 \\
\hline $\mathrm{Fe}_{2} \mathrm{O}_{3}$ & 4.10 & 3.5 & 3.04 & 3.26 & 4.08 & 3.60 & 3.06 & 4.51 & 3.58 \\
\hline $\mathrm{FeO}$ & 5.86 & 5.6 & 5.72 & 6.77 & 4.89 & 5.86 & 6.16 & 5.49 & 6.05 \\
\hline $\mathrm{MnO}$ & 0.19 & 0.18 & 0.13 & 0.16 & 0.15 & 0.17 & 0.16 & 0.14 & 0.16 \\
\hline $\mathrm{MgO}$ & 4.60 & 7.4 & 4.01 & 5.52 & 3.97 & 5.25 & 4.40 & 4.32 & 3.88 \\
\hline $\mathrm{CaO}$ & 9.27 & 9.9 & 9.77 & 9.52 & 9.12 & 9.67 & 9.74 & 8.42 & 9.09 \\
\hline $\mathrm{Na}_{2} \mathrm{O}$ & 3.05 & 3.2 & 3.05 & 2.59 & 3.08 & 2.58 & 2.94 & 3.11 & 3.14 \\
\hline $\mathrm{K}_{2} \mathrm{O}$ & 0.40 & 0.56 & 0.59 & 0.79 & 1.12 & 0.51 & 0.57 & 0.98 & 0.53 \\
\hline $\mathrm{P}_{2} \mathrm{O}_{5}$ & 0.22 & 0.28 & 0.18 & 0.18 & 0.15 & 0.22 & 0.17 & 0.31 & 0.21 \\
\hline $\mathrm{H}_{2} \mathrm{O}^{+}$ & 1.02 & 0.81 & 0.92 & 1.14 & 0.90 & 1.12 & 1.04 & 1.07 & 0.83 \\
\hline $\mathrm{H}_{2} \mathrm{O}^{-}$ & 1.23 & 0.86 & 0.49 & 0.41 & 1.09 & 1.16 & 0.24 & 0.45 & 0.25 \\
\hline $\mathrm{CO}_{2}$ & 0.07 & 0.08 & 0.02 & 0.01 & 0.07 & 0.11 & 0.32 & 0.43 & 0.04 \\
\hline Total & $\overline{100.34}$ & $\overline{100.62}$ & $\overline{99.57}$ & $\overline{100.23}$ & $\overline{100.60}$ & $\overline{100.29}$ & $\overline{100.43}$ & $\overline{100.51}$ & $\overline{100.15}$ \\
\hline
\end{tabular}

Analyses recalculated volatile-free and normalized to 100 percent

\begin{tabular}{|c|c|c|c|c|c|c|c|c|c|}
\hline $\mathrm{SiO}_{2}$ & 52.34 & 52.09 & 52.48 & 52.30 & 52.87 & 53.32 & 53.22 & 53.88 & 53.92 \\
\hline $\mathrm{TiO}_{2}$ & 1.56 & 0.96 & 1.38 & 1.60 & 1.40 & 1.37 & 1.35 & 1.60 & 1.50 \\
\hline $\mathrm{Al}_{2} \mathrm{O}_{3}$ & 17.85 & 15.98 & 19.16 & 16.93 & 18.77 & 16.85 & 17.91 & 16.84 & 17.67 \\
\hline $\mathrm{Fe}_{2} \mathrm{O}_{3}$ & 4.18 & 3.54 & 3.10 & 3.30 & 4.14 & 3.68 & 3.10 & 4.58 & 3.62 \\
\hline $\mathrm{FeO}$ & 5.98 & 5.66 & 5.83 & 6.86 & 4.96 & 5.99 & 6.23 & 5.57 & 6.11 \\
\hline $\mathrm{MnO}$ & 0.19 & 0.18 & 0.13 & 0.16 & 0.15 & 0.17 & 0.16 & 0.14 & 0.16 \\
\hline $\mathrm{MgO}$ & 4.69 & 7.48 & 4.09 & 5.59 & 4.03 & 5.36 & 4.45 & 4.38 & 3.92 \\
\hline $\mathrm{CaO}$ & 9.46 & 10.01 & 9.96 & 9.65 & 9.26 & 9.88 & 9.86 & 8.54 & 9.18 \\
\hline $\mathrm{Na}_{2} \mathrm{O}$ & 3.11 & 3.24 & 3.11 & 2.62 & 3.13 & 2.64 & 2.97 & 3.16 & 3.17 \\
\hline $\mathrm{K}_{2} \mathrm{O}$ & 0.41 & 0.57 & 0.60 & 0.80 & 1.14 & 0.52 & 0.58 & 0.99 & 0.54 \\
\hline $\mathrm{P}_{2} \mathrm{O}_{5}$ & 0.22 & 0.28 & 0.18 & 0.18 & 0.15 & 0.22 & 0.17 & 0.31 & 0.21 \\
\hline \multicolumn{10}{|c|}{ Modes } \\
\hline Plagioclase & 19.5 & 15.8 & 29.7 & 33.1 & 27.7 & 29.2 & 59.7 & 23.6 & 14.7 \\
\hline Clinopyroxene & -- -- & 4.7 & ---- & 0.5 & --- & 3.3 & 31.2 & 0.1 & 0.2 \\
\hline Orthopyroxene & $\ldots-$ & 1.2 & --- & $\cdots$ & --- & 1.4 & $\cdots$ & 2.9 & -- \\
\hline Olivine & 2.0 & 4.7 & 1.6 & 2.0 & 5.7 & 2.3 & 0.2 & 0.3 & 0.9 \\
\hline Fe-Ti oxide & $-\cdots-$ & --- & --- & --- & --- & --- & 2.8 & $-\cdots$ & --- \\
\hline Hornblende & $-\cdots$ & --- & $-\cdots$ & $--\cdot$ & $-\cdots$ & $-\cdots$ & $-\cdots$ & $--\cdot-$ & $-\cdots$ \\
\hline Quartz & $-\cdots$ & --- & --- & --- & -..- & ---- & $\mathrm{gl}+\mathrm{q} \quad 6.1$ & $-\cdots$ & -...- \\
\hline Groundmass & 78.5 & 73.6 & 68.7 & 64.4 & 66.6 & 63.8 & --- & 73.1 & 84.2 \\
\hline $\begin{array}{l}\text { No. of points } \\
\text { counted }\end{array}$ & 610 & 770 & 815 & 650 & 665 & 647 & 814 & 660 & 572 \\
\hline Texture & $\begin{array}{c}\text { seriate/ } \\
\text { intergranular }\end{array}$ & $\begin{array}{c}\text { seriate/ } \\
\text { intergranular }\end{array}$ & $\begin{array}{l}\text { porphyritic/ } \\
\text { intergranular }\end{array}$ & $\begin{array}{c}\text { seriate/ } \\
\text { intergranular }\end{array}$ & $\begin{array}{c}\text { seriate/ } \\
\text { intergranular }\end{array}$ & $\begin{array}{c}\text { seriate/ } \\
\text { intergranular }\end{array}$ & $\begin{array}{c}\text { seriate/ } \\
\text { intergranular }\end{array}$ & $\begin{array}{l}\text { porphyritic/ } \\
\text { intergranular }\end{array}$ & $\begin{array}{c}\text { seriate/ } \\
\text { intergranular }\end{array}$ \\
\hline
\end{tabular}


Table 2. Chemical analyses and modes of volcanic and hypabyssal intrusive rocks, Spirit Lake West quadrangle--

\begin{tabular}{|c|c|c|c|c|c|c|c|c|c|}
\hline \multicolumn{10}{|c|}{ Continued } \\
\hline Map No. & 19 & 20 & 21 & 22 & 23 & 24 & 25 & 26 & 27 \\
\hline $\begin{array}{l}\text { Field sample } \\
\text { Number }\end{array}$ & 7E29 & OR22 & 9R37 & 4E09 & $2 \mathrm{R} 35 \mathrm{C}$ & $1 \mathrm{E} 58$ & $88 \mathrm{E} 07$ & $1 E 77 \mathrm{~A}$ & $2 \mathrm{E} 90 \mathrm{~B}$ \\
\hline Latitude & $46^{\circ} 16^{\prime} 46$ & $46^{\circ} 17^{\prime} 42^{\prime \prime}$ & $46^{\circ} 17^{\circ} 00^{\prime \prime}$ & $46^{\circ} 15^{\prime} 42^{\prime \prime}$ & $46^{\circ} 16^{\prime} 36^{\prime \prime}$ & $46^{\circ} 16^{\prime} 50^{\prime \prime}$ & $46^{\circ} 16^{\prime} 59^{\prime \prime}$ & $46^{\circ} 17^{\prime} 14^{\prime \prime}$ & $46^{\circ} 17^{\prime} 51^{\prime \prime}$ \\
\hline Lonigtude & $122^{\circ} 11^{\prime} 21^{\prime \prime}$ & $122^{\circ} 12^{\prime} 44^{\prime \prime}$ & $122^{\circ} 10^{\prime} 13^{\prime \prime}$ & $122^{\circ} 07^{\prime} 53^{\prime \prime}$ & $122^{\circ} 14^{\prime} 22^{\prime \prime}$ & $122^{\circ} 10^{\prime} 50^{\prime \prime}$ & $122^{\circ} 14^{\prime} 30^{\prime \prime}$ & $122^{\circ} 14^{\prime} 52^{\prime \prime}$ & $122^{\circ} 07^{\prime} 55^{\prime \prime}$ \\
\hline Map unit & $\mathrm{Ta}_{1}$ & $\mathrm{Ta}_{1}$ & Tcp & Twr & Tia & $\mathrm{Ta}_{1}$ & Tia & Tia & Tid \\
\hline Rock type & $\begin{array}{l}\text { Basaltic } \\
\text { andesite }\end{array}$ & $\begin{array}{l}\text { Basaltic } \\
\text { andesite }\end{array}$ & $\begin{array}{l}\text { Basaltic } \\
\text { andesite }\end{array}$ & Granodiorite & Andesite & Andesite & Andesite & Andesite & Rhyolite \\
\hline Method & $\mathrm{XRF}$ & $\mathrm{RR}$ & XRF & XRF & $\mathrm{XRF}$ & $\mathrm{RR}$ & XRF & $\mathrm{RR}$ & $\mathrm{XRF}$ \\
\hline $\mathrm{SiO}_{2}$ & 53.8 & 54.0 & 55.8 & 57.4 & 57.9 & 58.8 & 59.4 & 59.8 & 73.8 \\
\hline $\mathrm{TiO}_{2}$ & 1.50 & 1.9 & 1.62 & 1.14 & 1.70 & 1.6 & 1.32 & 1.2 & 0.23 \\
\hline $\mathrm{Al}_{2} \mathrm{O}_{3}$ & 18.0 & 15.7 & 15.7 & 17.1 & 14.9 & 15.0 & 16.4 & 14.8 & 12.7 \\
\hline $\mathrm{Fe}_{2} \mathrm{O}_{3}$ & 3.18 & 5.3 & 3.66 & 1.52 & 2.26 & 3.2 & 2.42 & 2.6 & 1.54 \\
\hline $\mathrm{FeO}$ & 5.69 & 6.2 & 6.61 & 5.80 & 6.76 & 5.5 & 4.98 & 5.5 & 1.38 \\
\hline $\mathrm{MnO}$ & 0.15 & 0.2 & 0.18 & 0.12 & 0.16 & 0.16 & 0.16 & 0.15 & 0.04 \\
\hline $\mathrm{MgO}$ & 3.42 & 3.8 & 3.71 & 3.26 & 2.57 & 2.4 & 2.17 & 2.4 & 0.12 \\
\hline $\mathrm{CaO}$ & 8.81 & 7.9 & 7.68 & 6.46 & 6.33 & 5.5 & 5.68 & 5.7 & 0.68 \\
\hline $\mathrm{Na}_{2} \mathrm{O}$ & 3.05 & 3.4 & 3.27 & 3.51 & 3.80 & 3.8 & 4.62 & 4.2 & 3.94 \\
\hline $\mathrm{K}_{2} \mathrm{O}$ & 0.76 & 0.79 & 0.69 & 1.39 & .065 & 1.2 & 0.65 & 0.92 & 3.59 \\
\hline $\mathrm{P}_{2} \mathrm{O}_{5}$ & 0.24 & 0.35 & 0.24 & 0.20 & 0.36 & 0.44 & 0.31 & 0.58 & $<0.05$ \\
\hline $\mathrm{H}_{2} \mathrm{O}^{+}$ & 1.33 & 0.60 & 0.97 & 1.65 & 2.00 & 1.5 & 1.61 & 1.8 & 0.61 \\
\hline $\mathrm{H}_{2} \mathrm{O}^{-}$ & 0.53 & 1.2 & 0.44 & 0.36 & 0.76 & 0.51 & 0.55 & 0.53 & 0.16 \\
\hline $\mathrm{CO}_{2}$ & 0.02 & 0.04 & 0.06 & 0.06 & 0.04 & 0.04 & 0.02 & 0.02 & 0.09 \\
\hline Total & $\overline{100.48}$ & $\overline{101.38}$ & $\overline{100.63}$ & 99.97 & $\overline{100.18}$ & $\overline{99.65}$ & $\overline{100.29}$ & 100.20 & 98.88 \\
\hline
\end{tabular}

Analyses recalculated volatile-free and normalized to 100 percent

\begin{tabular}{|c|c|c|c|c|c|c|c|c|c|}
\hline $\mathrm{SiO}_{2}$ & 54.56 & 54.25 & 56.27 & 58.63 & 59.45 & 60.25 & 60.54 & 61.11 & 75.29 \\
\hline $\mathrm{TiO}_{2}$ & 1.52 & 1.91 & 1.63 & 1.16 & 1.75 & 1.64 & 1.35 & 1.23 & 0.23 \\
\hline $\mathrm{Al}_{2} \mathrm{O}_{3}$ & 18.26 & 15.77 & 15.83 & 17.47 & 15.30 & 15.37 & 16.72 & 15.13 & 12.96 \\
\hline $\mathrm{Fe}_{2} \mathrm{O}_{3}$ & 3.23 & 5.32 & 3.69 & 1.55 & 2.32 & 3.28 & 2.47 & 2.66 & 1.57 \\
\hline $\mathrm{FeO}$ & 5.77 & 6.23 & 6.67 & 5.92 & 6.94 & 5.64 & 5.08 & 5.62 & 1.41 \\
\hline $\mathrm{MnO}$ & 0.15 & 0.20 & 0.18 & 0.12 & 0.16 & 0.16 & 0.16 & 0.15 & 0.04 \\
\hline $\mathrm{MgO}$ & 3.47 & 3.82 & 3.74 & 3.33 & 2.64 & 2.46 & 2.21 & 2.45 & 0.12 \\
\hline $\mathrm{CaO}$ & 8.94 & 7.94 & 7.75 & 6.60 & 6.50 & 5.64 & 5.79 & 5.83 & 0.69 \\
\hline $\mathrm{Na}_{2} \mathrm{O}$ & 3.09 & 3.42 & 3.30 & 3.59 & 3.90 & 3.89 & 4.71 & 4.29 & 4.02 \\
\hline $\mathrm{K}_{2} \mathrm{O}$ & 0.77 & 0.79 & 0.70 & 1.42 & 0.67 & 1.23 & 0.66 & 0.94 & 3.66 \\
\hline $\mathrm{P}_{2} \mathrm{O}_{5}$ & 0.24 & 0.35 & 0.24 & 0.20 & 0.37 & 0.45 & 0.32 & 0.59 & 0.00 \\
\hline \multicolumn{10}{|c|}{ Modes } \\
\hline Plagioclase & 19.0 & 4.3 & 0.6 & 49.3 & $\operatorname{tr}$ & 0.2 & 3.6 & 3.7 & 3.6 \\
\hline Clinopyroxene & 0.4 & $---\cdot$ & ..... & 12.7 & $\operatorname{tr}$ & 0.1 & tr & 0.8 & 0.5 \\
\hline Orthopyroxene & $\ldots-$ & $-\cdots$ & $\ldots$ & 4.1 & $\ldots$ & $\operatorname{tr}$ & $\operatorname{tr}$ & 0.00 & \\
\hline Olivine & 0.7 & 0.2 & $-\cdots$ & $\cdots+$ & $-\cdots$ & $\ldots$ & $\ldots$ & $\cdots$ & --- \\
\hline Fe-Ti oxide & $\ldots$ & $\cdots$ & --- & 1.1 & --- & $-\cdots$ & tr & 0.1 & 0.3 \\
\hline Hornblende & --- & --- & $\cdots-$ & 0.4 & -..-- & $-\cdots$ & $-\cdots$ & ---- & $\ldots-$ \\
\hline Quartz & $\ldots$ & $\ldots$ & --- & $\cdots$ & $\cdots$ & --- & $-\cdots$ & --- & --- \\
\hline Groundmass & 79.9 & 95.5 & 99.4 & 32.4 . & 100.0 & 96.4 & 99.7 & 95.3 & 95.6 \\
\hline $\begin{array}{l}\text { No. of points } \\
\text { counted }\end{array}$ & 679 & 512 & 522 & 566 & 700 & 535 & 665 & 732 & 604 \\
\hline Texture & $\begin{array}{l}\text { seriate/ } \\
\text { intergranular }\end{array}$ & $\begin{array}{l}\text { micropor- } \\
\text { phyritic/ } \\
\text { intersertal }\end{array}$ & $\begin{array}{c}\text { aphyric/ } \\
\text { intergranular }\end{array}$ & $\begin{array}{l}\text { porphyritic/ } \\
\text { microcrys- } \\
\text { talline }\end{array}$ & $\begin{array}{l}\text { aphyric/ } \\
\text { hyalopilitic }\end{array}$ & $\begin{array}{l}\text { aphyric/ } \\
\text { pilotaxitic }\end{array}$ & $\begin{array}{l}\text { porphyritic/ } \\
\text { pilotaxitic }\end{array}$ & $\begin{array}{l}\text { porphyritic/ } \\
\text { felty }\end{array}$ & $\begin{array}{r}\text { porphyritic/ } \\
\text { spherulitic }\end{array}$ \\
\hline
\end{tabular}


$+$ 